\title{
Plasma technology in textiles
}

\author{
NIDHI SISODIA AND ABHA BHARGAVA
}

Received: 15.01.2016; Accepted: 27.05.2016

See end of the paper for authors' affiliations NIDHI SISODIA

Department of Textile Chemistry, Uttar Pradesh Textile Technology Institute,KANPUR (U.P.) INDIA Email : sisodianidhi@yahoo.com
ABSTRACT : This paper reports the studied available on the plasma technology in textiles. Plasma technology modifies the surfaces of textile materials concrete the way for the realization of new materials and of new research zones. This technology is environmentally technique and used for modifying the surface characteristics of a fabric or fibre without altering its basic properties.

KEY WORDS: Plasma technology, Textile

- HOW TO CITE THIS PAPER : Sisodia, Nidhi and Bhargava, Abha (2016). Plasma technology in textiles. Asian J. Home Sci., 11 (1) : 261-269, DOI: 10.15740/HAS/AJHS/11.1/261-269. 